\title{
CHEMICAL COMPOSITION AND BIOLOGICAL ACTIVITY OF TRAPA NATANS L.
}

\author{
Rosa Cukic Corovic ${ }^{1,2}$, Jovana Bradic ${ }^{3}$, Marina Tomovic ${ }^{3}$, Vera Dabanovic ${ }^{1,2}$, Vladimir Jakovljevic ${ }^{4,5}$, Gala Zarkovic ${ }^{1}$ and Zeljka Rogac ${ }^{6}$ \\ ${ }^{1}$ University of Montenegro, Faculty of Medicine, Podgorica, Montenegro \\ ${ }^{2}$ Pharmacy Health Institution of Montenegro „, Montefarm “, Podgorica, Montenegro \\ ${ }^{3}$ University of Kragujevac, Faculty of Medical Sciences, Department of Pharmacy, Kragujevac, Serbia \\ ${ }^{4}$ University of Kragujevac, Faculty of Medical Sciences, Department of Physiology, Kragujevac, Serbia \\ ${ }^{5}$ University IM Sechenov, Ist Moscow State University, Department of Human Pathology, Moscow, Russia \\ ${ }^{6}$ Clinical Center of Montenegro, Podgorica, Montenegro
}

\author{
HEMIJSKI SASTAV I BIOLOŠKA AKTIVNOST TRAPA NATANS L. \\ Rosa Čukić Ćorović ${ }^{1,2}$, Jovana Bradić3, Marina Tomović ${ }^{3}$, Vera Dabanović1,2, Vladimir Jakovljević4,5, Gala Žarković1 i Željka Rogač ${ }^{6}$ \\ ${ }^{1}$ Univerzitet Crne Gore, Medicinski fakultet, Podgorica, Crna Gora \\ ${ }^{2}$ Apoteka Zdravstvena ustanova Crne Gore „Montefarm“, Podgorica, Crna Gora \\ ${ }^{3}$ Univerzitet u Kragujevcu, Fakultet medicinskih nauka, Katedra za farmaciju, Kragujevac, Srbija \\ ${ }^{4}$ Univerzitet u Kragujevcu, Fakultet medicinskih nauka, Katedra za fiziologiju, Kragujevac, Srbija \\ ${ }^{5}$ Univerzitet IM Sečenov, 1. Moskovski državni univerzitet, Odeljenje za humanu patologiju, Moskva, Rusija \\ ${ }^{6}$ Klinički centar Crne Gore, Podgorica, Crna Gora
}

\begin{abstract}
Trapa natans L., water chestnut (indian name singada, montenegrin name kasaronja) belonging to Trapaceae family is annual aquatic floating herb native to Asia but widely distributed in the Europe and in North America. The presence of two species, Trapa natans L. and Trapa longicarpa M.Jank. ssp. scutarensis M.Jank has been confirmed on the Skadar lake in Montenegro. Trapa natans is a plant demonstrating promising pharmacological activity mostly due to the presence of its constituens, phenols and flavonoids, showed hepatoprotective potential, antioxidant, anti-inflammatory, antidiabetic, antifungal and in vitro antimicrobial activity.

Keywords: Trapa natans, water chesnut, pharmacology effects, medical use
\end{abstract}

\section{SAŽETAK}

Trapa natans L., vodeni kesten (indijsko ime singada, crnogorsko ime kasaronja) koji pripada porodici Trapaceae jednogodišnja je vodena plutajuća biljka poreklom iz Azije, ali široko rasprostranjena u Evropi i Severnoj Americi. Prisustvo dve vrste, Trapa natans L. $i$ Trapa longicarpa M.Jank. ssp. scutarensis M.Jank potvrdena je na Skadarskom jezeru u Crnoj Gori. Trapa natans je biljka koja pokazuje obećavajuću farmakološku aktivnost uglavnom zahvaljujući prisustvu njenih sastojaka, fenola i flavonoida, pokazala je hepatoprotektivni potencijal, antioksidativno, protivupalno, antidijabetičko, antimikotično $i$ in vitro antimikrobno delovanje.

Ključne reči: Trapa natans, vodeni kesten, farmakološki efekti, medicinska upotreba 


\section{INTRODUCTION}

Trapa natans L., water chesnut, belonging to Trapaceae family and it is annual aquatic floating herb native to Asia, where it is known for its local name Singhara (1). Nowdays plants from Trapa genus are widely distributed in the Europe and naturalized in North America (2). Number of Trapa species has not been precisely defined so far, however it is certainly more then 20 (3). A presence of two species, Trapa natans L. and Trapa longicarpa M.Jank. ssp. scutarensis M.Jank. has been confirmed on the Skadar lake in Montenegro (4). Local name for water chesnut in Montenegro is kasaronja and it's parts such a fruit with seed were of a great importance in the nutrition of population during the years of poverty (5). In Asian continent, including India and China, water chestnut has been widely used for medical purposes since ancient times, (6) however this plant species has not been use in traditional medicine in Montenegro.

Trapa natans Is one of the most important medicinal plants of Indian Ayurveda due to its use in the treatment of stomach disorders, genitourinary system, liver, kidney and spleen disorders (6).

Based on pharmacological potential Trapa natans L. has been recognized as the most significant plant species belonging to Trapa genus. Therefore this review will summarize the current knowledge from the available literature referring to Trapa natans.

\section{DESCRIPTION}

Trapa natans L. grows in lakes and some rivers requiring conditions such as sunny places and slightly acidic water.

It has surfacing and submerged leaves. Characteristics of triangular surfacing leaves involve toothed edge and an inflated petiole which forms a rosette on the surface of the water. Submerged leaves are feather-like and they are circled around the stem of the plant. White flowers are formed on the axils and in July come out to the surface and bloom. Fruit is in form of nut, and has a hard,,wooden“ surface with four sharp spines which are edible. Stems are rarely branching, long, rope-like and can attain lengths of up to 5 meters. The seeds germinate in the substratum, firmly attached to the lateral roots $(7)$.

\section{CHEMICAL COMPOUNDS}

Literature data indicate the presence of essential minerals, proteins, lipids, carbohydrates as well as vitamins (B1, B2, B5, B6, E, A, C), dietary fibers and polyphenols such as phenolic acids and flavonoids as well as hydrolyzable tannins in water chesnut (8). Peels of water chestnuts have been shown to have a much higher content of phenolic compounds than kernels (9). Ten phenolic compounds have been identified in Trapa natans leaf extract so far, while three phenolic acids, gallic, ellagic and ferulic acid, as well as quercetin 3-O-galactoside (hyperoside), are present in a large quantity comparing to other compounds (10).

\section{Aqueous extract of Trapa natans L. fruits}

The most significant compounds in the aqueous Trapa natans L. fruit extract are phenolics which have gained increased scientific attention due to their prominent free radical scavenging activity. There is certain evidence that the aqueous extract of Trapa natans L. fruit exert great in vitro antioxidant activity against free radicals due to it's polyphenolic content (9). (Table 1.)

Table 1. The total content of phenolic, flavonoid and tannin compounds in the aqueous

Trapa natans L. fruit extract

\begin{tabular}{|l|c|}
\hline $\begin{array}{l}\text { gallic acid equivalents/g of dry } \\
\text { material }\end{array}$ & $63.81 \mathrm{mg}$ \\
\hline rutin equivalents/g of dry material & $21.34 \mathrm{mg}$ \\
\hline tannin equivalent /g of dry material & $17.11 \mathrm{mg}$ \\
\hline \multicolumn{2}{|c|}{ (sourse reference: Malviya, N. et all. 2010) }
\end{tabular}

In addition, extract of Trapa natans L. in mentioned study showed a crucial property of protein oxidation inhibition. So far it has been known that only a few plant extract constituents exert that kind of activity which can inhibit the progression of a number of diseases implicating by oxidative stress (9).

\section{Trapa natans methanol leaf extracts}

Phytochemical analysis of methanol extract, as the least toxic when compared to acetone and ethyl acetate leaf extracts in the zebrafish (Danio rerio) model system, identified phenolic compounds such as p-hydroxybenzoic acid, phenolic acids and derivatives, flavonoids and flavonoid glycosides (10). (Table 2.)

Flavonoids are chemical compounds that protect cells against the damaging effects of reactive oxygen species, such as superoxide, singlet oxygen, hydroxyl radicals, peroxyl radicals and peroxynitrite. There are many epidemiological studies that have shown flavonoid intake is inversely related to mortality due to cardiovascular disease (15).

Phenolics in plant species form one of the major groups of compounds which primary act as antioxidants. Antioxidant activity of phenolics is based on absorbtion and neutralization of free radicals, quenching singlet and triplet oxygen or decomposing peroxides (16). There are suggestions that polyphenolic compounds have inhibitory effects on mutagenesis and carcinogenesis in humans, by daily ingesting approximately $1.0 \mathrm{~g}$ from a diet rich in vegetables and fruits (17). 
Table 2. Content of phenolic compounds of methanolic Trapa natans L. leaf extract

\begin{tabular}{|c|c|c|}
\hline Phenolic acids and their derivatives & Flavonoids & Flavonoid Glycosides \\
\hline $\begin{array}{ll} & \text { Gallic acid hexoside isomer } 1 \\
& \text { and isomer } 2 \\
> & \text { Gallic acid } \\
> & \text { Protocatechuic acid } \\
> & \text { p-Hydroxybenzoic acid } \\
> & \text { p-Coumaric acid hexoside } \\
> & \text { Caffeic acid } \\
> & \text { p-Coumaric acid } \\
> & \text { Ellagic acid } \\
> & \text { p-Coumaroyl-digalloyl-O-glucose } \\
> & \text { Ferulic acid }\end{array}$ & $\begin{array}{ll}> & \text { Quercetin } \\
> & \text { Pinobanksin } \\
> & \text { Naringenin } \\
> & \text { Rhamnetin }\end{array}$ & $\begin{aligned}> & \text { Naringenin-7-O-hexoside } \\
> & \text { Kaempferol di-O-hexoside isomer } 1 \\
> & \text { Rutin } \\
> & \text { Kaempferol-3-O-glucoside } \\
& \text { (Astragalin) } \\
> & \text { Quercetin 3-O-rhamnoside } \\
> & \text { Quercetin 3-O-galactoside }\end{aligned}$ \\
\hline
\end{tabular}

(sourse reference: Aleksic, I. et al. 2018)

\section{Inorganic constituents of Trapa natans}

Trapa natans contains many inorganic constituents such as minerals, phosphorus, calcium, iron, copper, magnesium,manganese, sodium and potassium (11). Mineral contents of $100 \mathrm{~g}$ of the seeds were $32 \mathrm{mg}$ (12).

\section{PHARMACOLOGYCAL PROPERTIES OF EXTRACTS OF TRAPA NATANS PARTS}

Several studies demonstrated promising pharmacological activity of Trapa natans extract mostly dedicated to the presence of phenols and flavonoids.

\section{Hepatoprotective activity}

Trapa natans fruit peel ethanolic extract showed hepatoprotective potential against antitubercular drugs induced hepatotoxicity. Hepatotoxicity was induced in rats by intraperitoneal injection of antitubercular drugs and the level of marker enzymes confirming induced hepatotoxicity was measured. T. natans peel extract aplication (200 and 400 $\mathrm{mg} / \mathrm{kg}$ ) resulted in significant reduction in liver marker enzymes and antioxidant parameters (13). Study also showed that T.natans ethanolic root extract and its derived fractions have significant protective effect against hepatotoxicity and lipid peroxidation. Identification of ferulic acid and caffeic acid in Trapa natans extract might explain the mentioned activity due to antioxidative nature of both constituents (1).

\section{Anti-inflammatory activity}

As mentioned earlier, phenolic compounds such as gallic acid were detected in water chesnut extracts. (10). It seems that gallic acid have useful pharmacologycal properties, including antioxidant, anti-inflammatory, anti-viral, and anticancer activities (18)(19). Consequently, gallic acid has a main anti-inflammatory activity in water chesnut extract and there are evidences that its use may be a posible therapeutic agent against skin inflammatory disorders (20).

\section{Antidiabetic activity}

Trapa natans fruit peel methanol extract has shown antidiabetic activity against streptozotocin induced diabetic rats. One of the main advantages is that ethanolic extract of Trapa natans roots and its derived fractions can slow down the progression of hyperglycemia without inducing hypoglycemic effect. Antihyperglycemic activity of Trapa natans might be attributed to the presenceof ferulic acid and caffeic acid (14). Ferulic acid is known to reduce oxidative stress and hyperglycemic response while caffeic acid has generative effect on Langerhans islets following reduction in expression of glucose transporter 2 in liver and consequently, reduce hyperglycemic effect (21)(22).

\section{Antifungal activity}

An isolated peptide from Trapa natans fruits possesses antifungal activity against Candida tropicalis. In one study, TnAFP1, one uncommon small antifungal peptide with molecular mass of $1230 \mathrm{Da}$ was isolated and identified from the fruits of T. Natans. Antifungal peptide from T.natans fruit showed better antifungal activity against $C$. tropicalis with inhibitory effect on biofilm formation, compare to several previously known peptides (23).

\section{Anthelmintic activity}

Methanol extracts of fruit peel also have anthelmintic activity acording to study. It showed dose-dependent activity on adult Indian earthworms Pheritima posthuma and aquarium worm Tubifex tubifex. Three concentrations viz., 5, 10 and $20 \mathrm{mg} / \mathrm{ml}$ of aqueous and methanolic extracts of fruit peels and root were studied to determine the time of paralysis and time of death and results showed that methanolic extracts possess significant anthelmintic activity at highest concentration of $20 \mathrm{mg} / \mathrm{ml}$. Piperazine citrate in $10 \mathrm{mg} / \mathrm{ml}$ 
concentration was evaluated as standard reference and distilled water as control (24). Flavonoids, tannins and polyphenolic compounds show anthelmintic activity acording to literature and it is expected that methanolic extracts of Trapa natans peel exert that kind of pharmacological effect (25)(26).

\section{Antimicrobial activity}

Several extracts of fruit peel showed in vitro antimicrobial activity. Trapa natans L. fruit peel extracted in different solvents with increasing polarity: 1,4-dioxan, chloroform, acetone, dimethylformamide, ethanol and water showed diferent intensity. Traditional use of water chesnut was mostly referring to its water extract, but founded studies pointed that the plant extracts, extracted in different organic solvents showed profoundly distinct antibacterial activity than aqueous extract. Maximum efect was with dimethylformamide while minimum was with petroleum ether extract. Pseudomonas aeruginosa, $P$. vulgaris and $P$. pseudoalcaligenes were completely resistant at all extracts, while best antibacterial activity was shown against $P$. Putida (best antibacteral effect shown by 1,4-dioxan extract) followed by $P$. testosterone and $P$. morganii respectively while $P$. mirabilis was inhibited by 4 of the solvents only $(1,4$-dioxan, acetone, dimethylformamide, ethanol). Amongst Klebsiella strains, $K$. pneumoniae showed good antibacterial activity with all the solvents. Study showed maximum antibacterial activity against Gram negative bacteria (27).

\section{TRADITIONAL USE}

Trapa natans in Montenegro has been predominantly used in nutrition, however its therapeutical potential in traditional medicine has not been clarified so far (5). On the other hand, in Asia continent including India and China, water chestnut was often used for medical purposes. Since ancient times, good pharmacological properties of this plant species as antipyretic, diuretic, hemostatic, constipating, antidiarrheal, have been recognized and applied in traditional Chinese and Indian medicine (6) . It has been traditionally used in India in a form of liniments made from the fruits and as a cure for rheumatism, sore and sunburns (28).

\section{CONCLUSIONS}

There are scientific reports confirming pharmacological properties of Trapa natans in various diseases and conditions. Nevertheless the full therapeutic potential of this plant species has yet to be understood and discovered.

\section{LITERATURE}

1. Kharbanda, C., Sarwar Alam, M., Hamid, H., Bano, S., Haider, S., Nazreen, S., ... Javed, K. (2014). Trapa natans L. root extract suppresses hyperglycemic and hepatotoxic effects in STZ-induced diabetic rat model. Journal of Ethnopharmacology

2. Cook, C.D.K., 1990. Aquatic Plant Book. SPB Academic Publishing, The Hague.

3. Takano, A., \& Kadono, Y. (2005). Allozyme variations and classification of Trapa (Trapaceae) in Japan. Aquatic Botany, 83(2), 108-118.

4. Talevska M., Petrovic D., Milosevic D., Talevski T., Maric D., Talevska A.. (2014) Biodiversity of Macrophyte Vegetation from Lake Prespa, Lake Ohrid and Lake Skadar. Biotehnology and Biotehnological Equipement Journal. 23: sup1.931-935

5. Bojović D, Cupara S, Tadić V, Potpara Z, 2010. Autochthone edible plants of Montenegro, Rational therapy, Medrat, Vol 2, No 1, 17-25

6. Adkar, P., Dongare, A., Ambavade, S., and Bhaskar, V.H. (2014) Trapa bispinosa Roxb.: A Review on Nutritional and Pharmacological Aspects. Adv Pharmacol Sci 2014, 959830.

7. Bercu R, Histoanatomy of the leaves of Trapa natans (Trapaceae), Phytologia Balcanica 10 (1): 51-55, Sofia, 2004

8. Huang, H.C. et all. (2016) Hypoglycemic Constituents Isolated from Trapa natans L. Pericarps. J Agric Food Chem 64, 3794-3803.

9. Malviya, N., Jain, S., Jain, A., Jain, S., and Gurjar, R. (2010) Evaluation of in vitro antioxidant potential of aqueous extract of Trapa natans L. fruits. Acta Pol Pharm 67, 391-396.

10. Aleksic, I., Ristivojevic, P., Pavic, A., Radojević, I., Čomić, L. R., Vasiljevic, B., ... Senerovic, L. (2018). Anti-quorum sensing activity, toxicity in zebrafish (Danio rerio) embryos and phytochemical characterization of Trapa natans leaf extracts. Journal of Ethnopharmacology, 222, 148-158.

11. Khare CP. Indian Medicinal Plants: An Illustrated Dictionary. Berlin, Germay: Springer; 2007.

12. Alfasane MA, Moniruzzaman K, Rahman MM. Biochemical composition of the fruits of water chestnut (Trapa bispinosa Roxb) Dhaka University Journal of Biological Sciences. 2011;20(1):95-98.

13. Hussain T, Subaiea G. M., Firdous H. Hepatoprotective Evaluation of Trapa natans against Drug-induced Hepatotoxicity of Antitubercular Agents in Rats. Pharmacogn Mag. 2018 Apr-Jun; 14(54): 180-185.

14. PK Das, S Bhattacharya, JN Pandey, Biswas M. Antidiabetic activity of Trapa natans fruit peel extract against streptozotocin induced diabetic rats. Global Journal of Pharmacology 5 (3): 186-190, 2011. 
15. Binte Wahed T, Islam F, Sarkar R, Binte Wahed S. Phytochemical, antioxidant and citotoxicity study of the methanolic extracts of leaves of Trapa bispinosa Roxb. International Journal of Pharmaceutical Sciences and Research (2014), Vol. 5, Issue 10

16. Osawa T: Novel Natural Antioxidants for utilization in food and biological systems. In I, Uritani, V, V, G arica, E.M. Mendoza (Eds.), Posthavest biochemistry of Plant food-materials in the tropics. Japan Scientific Press 1994; pp. 241-251. Tokyo, Japan.

17. Tanaka M, Kuie CW, Nagashima Y and Taguchi: Applications of antioxidative Maillard reaction products from histidine and glucose to sardine products. Nippon suisan Gakaishi 1998; 54: 1409-1414.

18. Kroes BH, van den Berg AJ, Quarles van Ufford HC, van Dijk H, Labadie RP. Anti-inflammatory activity of gallic acid. Planta Med. 1992 Dec; 58(6):499-504.

19. Chuang CY, Liu HC, Wu LC, Chen CY, Chang JT, Hsu SL. Gallic acid induces apoptosis of lung fibroblasts via a reactive oxygen species-dependent ataxia telangiectasia mutated-p53 activation pathway. J Agric Food Chem. 2010 Mar 10; 58(5):2943-51.

20. Bora Kim, Jin Eun Kim, Byung-Kook Choi, Hyun-Soo Kim. Anti-Inflammatory Effects of Water Chestnut Extract on Cytokine Responses via Nuclear Factor-kB-signaling Pathway. Biomol Ther (Seoul) 2015 Jan; 23(1): 90-97.

21. Ohnishi, M., Matuo, T., Tsuno, T., Hosoda, A., Nomura, E., Taniguchi, H., Sasaki, H., Morishita, H., 2004. Antioxidant activity and hypoglycemic effect of ferulic acid in STZ-induced diabetic mice and KK-Ay mice. BioFactors $21,315-319$.

22. Jung, U.J., Mi-Kyung, L., Park, Y.B., Seon-Min, J., Myung-Sook, C., 2006. Antihyperglycemic and antioxidant properties of caffeic acid in $\mathrm{db} / \mathrm{db}$ mice. J. Pharmacol. Exp. Ther. 318, 476-483.
23. Mandal, S. M., Migliolo, L., Franco, O. L., \& Ghosh, A. K. (2011). Identification of an antifungal peptide from Trapa natans fruits with inhibitory effects on Candida tropicalis biofilm formation. Peptides, 32(8), 17411747.

24. Verma VK, Sarwa K, Kumar A, 2013, Anthelmintic Activity of Fruit Peel and Root Extracts of Trapa natans L. var. bispinosa Roxb, Academic Journal of Plant Sciences 6 (2): 73-76

25. Bate Smith, E.C., 1962. The phenolic constituent of plants and their taxonomic significance, dicotyledons. J. Linn Soc. Bot., 58: 95-103.

26. Shrestha, B.H., V.D. Bassnett, Babu and S.S. Patel, 2009. Anthelmintic and antimicrobial activity of the chloroform extract of Pergularia daemia Frosk. leaves. Adv. Pharamcol. Toxicol., 10: 13-16.

27. Parekh J., Chanda S. 2007. In vitro antimicrobial activity of Trapa natans L. fruit rind extracted in different solvents, African Journal of Biotechnology, Vol. 6 (6), pp. 766-770

28. Zhao, W., Niu, F., Li, J., Dong, Q., Hang, Z., 2009. Components of volatile oil from water-caltrop and their antitumor effect in vitro. Chem. Res. Chin. Univ. 25, 56-59. 